\title{
Classifying vocabulary in Google Sheets to improve word recognition and reading comprehension in EFL learners: an action research study
}

\section{Classificando o vocabulário no Google Planilhas para melhorar o reconhecimento de palavras e a compreensão de leitura em alunos de English as Foreign Language (EFL): um estudo de pesquisa-ação}

\author{
Gabriela Katherine Almachi Granda ${ }^{1}$, Maria Rossana Ramirez-Avila ${ }^{2}$ \\ ${ }^{1}$ Universidad Técnica de Babahoyo, Los Rios, Ecuador. ORCID: https://orcid.org/0000-0002-0633-6037 \\ 2 Universidad Casa Grande, Guayaquil, Ecuador. ORCID: https://orcid.org/0000-0002-4745-2245
}

Mail to/Autor para correspondência/Correo a: Gabriela Katherine Almachi Granda, galmache@utb.edu.ec

Submitted/Recibido: 05 de maio de 2020; Approved/Aceptado: 25 de julho de 2020

Copyright (c) 2020 Granda \& Ramirez-Avila. All journal content (including directions, editorial policy and templates) is under a Creative Commons license Attribution-NonCommercial-ShareAlike 3.0 Non Adapted. By being published by this journal, articles are free to use in educational, research and non commercial environments, with mandatory attribution of authorship. To further information check http://revistas.ufpr.br/atoz/about/submissions\#copyrightNotice.

\begin{abstract}
Introduction: University students had problems understanding texts. This study aimed at analyzing the effects of classifying vocabulary into parts of speech through Google Sheets to improve students' word recognition and its incidence in reading comprehension. It analyzes the students' perspectives on learning vocabulary. Method: The study used an action research method, pre-post surveys, and pre-post tests were applied. Results: The findings proved that classifying "parts of speech" facilitated the improvement of reading comprehension skills, with an effect size of $d=0.81$. Second, it confirmed that knowing vocabulary form raises students' awareness to identify and classify words correctly Third, the application of the study changed positively participants' perspectives regarding learning vocabulary. Conclusion: Therefore, due to Ecuadorian learners' need in training and to the little literature about parts of speech, the positive results of this action research can be a venue to reduce those gaps
\end{abstract}

Keywords: Reconhecimento de palavras; Partes do discurso; Google Planilhas

\begin{abstract}
Resumo
Introdução: Estudantes universitários tiveram problemas para entender textos. Assim, este estudo teve como objetivo analisar os efeitos da classificação do vocabulário em partes do discurso por meio do Google Planilhas para melhorar o reconhecimento de palavras dos alunos e sua incidência na compreensão da leitura. Além disso, o estudo analisou as perspectivas dos estudantes sobre o vocabulário de aprendizagem. Metodologia: O estudo utilizou um método de pesquisa-ação, foram aplicadas um pré e pós questionário e um pré e pós teste. Resultados: Os resultados provaram que a classificação de "partes do discurso" facilitou a melhoria das habilidades de compreensão leitora, com um tamanho de efeito de $d=0,81$. Segundo, confirmou que conhecer o formulário de vocabulário aumenta a conscientização dos alunos para identificar e classificar as palavras corretamente Terceiro, a aplicação do estudo mudou positivamente a perspectiva dos participantes em relação a aprendizagem de vocabulário. Conclusão: Portanto, devido à necessidade de treinamento dos alunos equatorianos e à pouca literatura sobre partes do discurso, os resultados positivos dessa pesquisa-ação podem ser uma oportunidade para reduzir essas lacunas.
\end{abstract}

Palavras-chave: Word recognition; Parts of speech; Google sheets

\section{INTRODUCTION}

English involves four macro skills. One of those is reading. Researchers coincide that good readers could transfer strategies from L1 to L2 and vice versa because language transfer is bidirectional (Celce-Murcia, Brinton, and Snow, 2014; Kartushina, Frauenfelder, and Golestani, 2016). Moreover, reading comprehension promotes 21st skills such as communication, collaboration, critical thinking, and curiosity (Scott, 2015).

However, UNESCO (2014) informed that the youth illiteracy in their mother tongue (L1) is high in reading. It also highlighted that learners who had a low-income are unable to read a sentence. The Third Regional Comparative and Explanatory Study (TERCE) measured the learning achievement of third and sixth Latin American graders in different aspects, one of those aspects is Reading in L1 (Flotts et al., 2016). These tests showed that Ecuador has an average of 698 out of 1000. The general mean of all the countries evaluated was 700 . It implies that Ecuador does not differ statistically from it.

In Ecuador, statistics show that reading in L1 practice remains a challenge since $26 \%$ of Ecuadorian do not have the habit of reading. A percentage of $56.8 \%$ reported that they were not interested in reading (Instituto Nacional de Estadísticas y Censos, 2012). Besides, in the rural areas of Ecuador, the situation is similar due to illiteracy. It is an issue that prevents teenagers from developing basic competencies (UNESCO, 2014). Based on the facts mentioned above, Ecuadorian students need training in reading skills. These facts were confirmed by the results of a reading comprehension test. Participants of this study got a mean of 43 out of 100, which showed 
poor performance in this skill. Similarly, a preliminary survey about students' perceptions towards reading and vocabulary showed that 17 participants considered the passages in English difficult. They also thought that learning vocabulary in English was complex. To this end, extensive research indicates that vocabulary form enhances not only learning English in general (Cabrera, Castillo, González, Quiñónez, and Ochoa, 2018; Nunan, 1991), but also reading comprehension specifically (Ibrahim, Sarudin, \& Muhamad, 2016).

Technological tools and applications have been implemented to help teachers around the world to encourage students to enhance their English learning outcomes (Hubbard, 2009; Jarvis and Krashen, 2013). Besides, the findings of a study done in Ecuador by Solano, Cabrera, Ulehlova, and Espinoza (2017) confirmed that technology is not commonly used in English classes. Moreover, a preliminary survey applied to participants of this study about the use of Google Sheets showed that 18 out of 26 were familiar with its use to present school work but not to learn vocabulary.

It's worth saying that some studies support the use of grammar to teach vocabulary and improve reading (Nation, 2001; Proctor, Silverman, Harring, and Montecillo, 2012; Richards and Schmidt, 2002). The meaning of the words and functions of the different parts of speech promotes syntax. It implies that it facilitates readers to make connections and to make the reading flow with a concordance (Poulsen \& Gravgaard, 2016). On the other hand, although there is very little literature indicating that classifying vocabulary into parts of speech improves reading comprehension (Hazaea \& Alzubi, 2016), the importance of vocabulary form to enhance comprehension supports the application of using the classification of the parts of speech.

Moreover, there has not been found any literature that evidences the contrary, specifically regarding classifying vocabulary into parts of speech. However, some findings have proved a different point of view about parts of speech in reading comprehension and about vocabulary itself (Hatami, 2017; Oh, 2015).

Having detected the difficulties of the participants in this study in reading due to their lack of vocabulary, and the gap of related literature, this action research was implemented to measure the following questions: 1 . To what extent does "classifying vocabulary into parts of speech" through the use of Google Sheets improve reading comprehension skills? 2. To what extent do students identify parts of speech and classify them? 3. Do students' perspectives of learning vocabulary change as a result of the innovation?

\section{LITERATURE REVIEW}

\section{Reading Comprehension: Skills Development}

Reading comprehension is the skill that enables the reader to process and understand a text, to make connections with what the reader already knows, and to apply it in the same or new context. According to Pearson, Valencia, and Wixson (2014), reading comprehension involves the interaction between the reader, the text, and the activity or purpose of the reading. Catts and Kamhi (2017, p. 73) stated that "the reader brings a set of cognitive-linguistic abilities, motivations, interests, and background knowledge to the task of reading".

Some authors support the use of Computer Assisted Language Learning (CALL) in reading comprehension. Abdullah (2014) agreed that CALL enhances the reading language process. Also, students whose attitude toward CALL was positive got better results after taking the post-reading test in comparison with those who had a negative attitude. Additionally, a study conducted in Ecuador showed that the use of CALL tools is helpful to increase students' reading scores (Cabrera et al., 2018).

A study developed by Binder, Cote, Lee, Bessette, and Vu (2016) demonstrated a high correlation between vocabulary depth mastery and acquiring a high level of reading comprehension skills. Since being aware of the meaning of the words enabled the participants to have a deeper understanding of the context and a better representation of the text. Also, Skehan stated that learners need to enrich their repertoire of formulaic expressions to get fluency as well as rule-based competence consisting of how to use specific grammatical components to master complexity and accuracy (as cited in Ellis, 2005).

Ibrahim et al. (2016) advocated that vocabulary size enhances reading comprehension. Their study was conducted at a public university in Malaysia, and it showed a statistically significant relationship at $\mathrm{p}<0.01$ level between the students' reading comprehension skills and the vocabulary size they master. In other words, the higher the students' mastery in vocabulary size was, the higher was the grade in reading comprehension.

\section{Vocabulary Acquisition as a Support for Reading Comprehension Skills Development}

Vocabulary depth involves knowledge of semantic, syntactic, and morphological components of each word. It plays a significant role in writing and reading, as well as in the development of higher-order literacy skills (Proctor et al., 2012). Semantics is the linguistic science that studies the meaning of the words, including how form and meaning are related. The focus is on meanings that stem from the sociocultural context and the speaker's intentions (Slabakova, 2018; Yurtbasi, 2015). According to Poulsen and Gravgaard (2016), the syntax allows readers to activate word meanings and make connections with propositions in a way it makes sense and has a 
concordance. They also said that syntax guides the readers on how the word meanings should be integrated into propositional meaning so that they make reasonable inferences about the text.

For Schmitt and Meara (1997), vocabulary size is regarded as how many words are known, and vocabulary depth refers to how well those words are understood. Lexical knowledge and word association need to be considered to deal with vocabulary size and depths (Çakir, Ünaldi, Arslan, \& Kiliç, 2016). Besides, there are two kinds of vocabulary learning approaches to increase exposure to vocabulary: intentional and incidental learning. Intentional is when it is planned to learn. It involves learning synonyms, antonyms, word substitutions, among others. Learners know the meaning of new words without going through cognitive processes. On the contrary, incidental is the process to learn vocabulary without the intention of doing so. It is an indirect way to learn as a product of other activities. It means the learners' ability to guess the meaning of the words they find in the reading texts. It involves cognitive processes (Nation, 2001; Richards and Schmidt, 2002).

In contrast to the previous findings, a study conducted by Oh (2015) showed that vocabulary as a unique construct did not contribute to enhancing reading and listening comprehension, but together with knowledge of grammar and sentence processing speed did. Similarly, none of these constructs made a unique contribution.

\section{Parts of Speech}

One of the dimensions of Vocabulary knowledge is part of speech. Schachter and Shopen (2010) stated this classification corresponds to a major class of words, and they are known because of their grammar function in the language. Melinger and Koenig (2007) suggested that the lexical organization is done according to the syntactic dimensions of part-of-speech. According to Lin (2014), the analysis of parts of speech provides English learners an insight into how native English speakers use lexical resources in the language. The four basic parts of speech are the classes of nouns, verbs, adjectives, and adverbs. Nouns refer to the name of most people, places, and things. Verbs express actions and processes. Adjectives qualify nouns. And, adverbs modify an adjective, verb, or another adverb (Schachter \& Shopen, 2010).

A study conducted by Purgina, Mozgovoy, and Ward (2017) confirmed how the recognition and use of the different parts of speech helped students to acquire vocabulary indirectly. The process was done through "Word Bricks," a MALL app. It facilitated participants to construct grammatically correct sentences. This enabled participants to use bricks and connectors of different colors to differentiate the parts of speech, and thus to improve their vocabulary indirectly. Hazaea and Alzubi (2016) pointed out that classifying parts of speech and recognizing new words facilitated by MALL apps helped learners in the reading process by making connections, building literal and inferential meaning, constructing meaning while critically analyzing texts.

\section{Google Sheets}

One of the tools of Google Drive is Google sheets. It is free of charge and works on devices that are connected to the internet. It is necessary to have a Gmail account since it gives access to the sheets and allows users to share the document (Choi, Lam, Li, \& Wong, 2018). Manowong (2017) researched how online tools such as Google Docs, Canvas, and Padlet affect English reading for EFL learners and revealed that it promoted the critical and creative thinking as well as collaborative skills. Sadik (2016) investigated if students accepted Google Sheets as a useful application to support the document sharing, results showed that they found it easy to open, edit, and share documents, and had good perceptions toward the application. The study recommended implementing Google Sheets to promote learning activities in creative and collaborative settings (Sadik, 2016). Some studies are referring to the use of Google Sheets as a tool to support business learning, mathematics, and English learning (Chiner and Garcia-Vera, 2017; Sevilla-Pavón, 2016). However, there is not a study regarding the use of it for language learning or, in this case, for classifying parts of speech to improve reading comprehension.

\section{Perspectives}

Students' perspectives on learning vocabulary are remarkable to prove the importance of the present research. Chou (2018) asserted that passive learners in Taiwan eventually changed their perspectives after the implementation of an innovation that involved interactive strategies to enhance their English learning regarding interactive vocabulary. It implies that students' perspectives might change after the application of real useful innovations.

\section{METHODOLOGY}

According to Edwards-Groves and Kemmis (2016), action research is when teachers engage in research to take a specific action of improvement and share the findings. In this case, this innovation involves enhancement in reading. Therefore, action research was applied. The instruments provided quantitative data.

\section{Participants}

Twenty-six students formed the target group. Their level was A1 according to the CEFR. The participants were from a public university in Ecuador. They attended the second level course, out of six levels in the language 
center. The sessions were on Tuesdays and Thursdays from 5:00 pm. to 8:00 pm. It is a convenience sample since the class was assigned to the researcher.

First, some instruments were included at the beginning to describe the participants. One of them was a demographic survey that included English, and technology skills knowledge. Another was an MM online proficiency to know the students' level to find suitable reading texts that match their level (MM placement test, n.d.).

The demographic survey reported that most of the students (24) regarded themselves as beginner language learners. It coincided with the results of the proficiency test, which reported that 25 out of 26 learners were A1. The demographic survey also informed that learners felt capable of using technology. Consequently, the induction of the use of Google drive was not extensive.

\section{Instruments}

To address the first research question: To what extent does "classifying vocabulary into parts of speech" through the use of Google Sheets improve reading comprehension skills? The instrument applied was a pre/post-test to measure the effects of the innovation. The pre-post tests were divided into two parts. The first one was about reading comprehension, composed of skimming and scanning questions. The second part tested students' knowledge of parts of speech. The first part was considered to answer this question.

The pre-test was an adaptation of a reading comprehension test for A1 students (Grammarbank, n.d.). This pre-test is normally used in the language center where this study took place to test students with similar demographic characteristics. Three experts validated the content of the pretest. The post-test was an adaptation of the test of Unit 1 of the textbook assigned to this class. It was designed by the Oxford University Press (Lynn, 2015). This test was created with the specific purpose to test reading comprehension to A1 learners. Similar to the pre-test, three professors checked the tests to prove its validity. The timing for both of them was 40 minutes.

To answer the second research question: To what extent do students identify parts of speech and classify them? A comparison of the number of words students could classify in the second part of the pre and post-test was made. The second part contained a chart with four columns, named noun, adverb, verb, and adjective. Learners had to go through the reading passages, identify the different parts of speech, and classify them in the table. The pre and posttest and the learning process about the classification of the parts of speech were piloted with a group of A1 learners who attended classes in the previous semester in the same university.

Finally, to address the third research question: Do students' perspectives of learning vocabulary change as a result of the innovation? Pre-post surveys regarding students' perspectives towards vocabulary for reading comprehension were applied. The pre-survey presented a Cronbach's Alpha of 0.903 and 0.902 in the post-survey. The pre-survey was composed of eight check components, with the categories of totally agree, agree, neutral, disagree, and totally disagree. The post-survey was composed of thirteen check components, with the categories of totally disagree, disagree, neutral, agree, and totally agree. The instruments were piloted with a group of A1 students in a previous class. The survey was based on the Common European Framework of Reference. The survey items were obtained from the "can do in reading "parts for A1 and A2 learners. Additionally, the items about parts of speech were added to make it more specific.

\section{Data Analysis}

To determine if there was an improvement in reading comprehension, students' grades of the first section of pre-post tests were tabulated in an excel spreadsheet and saved to then be transferred to the SPSS 20 program to generate descriptive statistics. Then, Cohen's $d$ was calculated to get the effect size. These results were represented in a table.

To obtain the total of the number of words students classified correctly in the pre-posttest, excel was used. Four columns (noun, adverb, verb, and adjective) were tabulated with the number of words every candidate could complete in the pre-test chart. Additionally, the means of the four parts of speech of the pre-test were obtained. Then, the same process was applied for the post-test to make a comparison.

The results of the surveys to know students' perspectives were organized by frequencies. They are presented in a table.

\section{RESULTS}

Table 1 shows the results of the first part of the pre and post-tests regarding reading comprehension. The table illustrates that the mean of the post-test is higher than the pre-test, and an increase in the minimum of the grades in the post-test. These results present a large effect size of Cohen's $d=0.81$ (Kelley \& Preacher, 2012). Furthermore, the $p$ value was 0.000 , which means the results did not happen by chance. In other words, the data indicates that students' reading comprehension skills improved after the intervention. 


\begin{tabular}{lllllll}
\hline & N & Min & Max & Mean & SD & Mean Difference \\
\hline Pretest & 26 & 6 & 83 & 37.12 & 21.349 & -15.731 \\
\hline Postest & 26 & 26 & 83 & 52.85 & 17.01 & \\
\hline
\end{tabular}

Table 1. Reading comprehension pre and posttests

The second research question: To what extent do students identify parts of speech and classify them correctly? A comparison between the number of words students could classify correctly in the second part of the pre and post-tests is compared in table 2 .

\begin{tabular}{lccccccccc}
\hline $\begin{array}{l}\text { Parts of } \\
\text { Speech }\end{array}$ & \multirow{N}{N}{} & \multicolumn{4}{c}{ Pretest } & \multicolumn{4}{c}{ Postest } \\
\cline { 3 - 10 } & & Min & Max & Mean & SD & Min & Max & Mean & SD \\
\hline Noun & 26 & 0 & 4 & 0.69 & 1.490 & 1 & 15 & 8.19 & 5.162 \\
\hline Adverbs & 26 & 0 & 2 & 0.15 & 0.464 & 0 & 4 & 1.88 & 1.451 \\
\hline Verbs & 26 & 0 & 9 & 3.69 & 3.234 & 3 & 15 & 10.65 & 3.730 \\
\hline Adjectives & 26 & 0 & 4 & 0.65 & 1.164 & 1 & 15 & 6.23 & 4.217 \\
\hline
\end{tabular}

Table 2. Comparison of the average number of words classified correctly in the pre and posttests

Table 2 displays that there was an improvement in the number of words students classified correctly in the post-test. The mean number of every part of speech on the post-test was higher than in the pre-test. The most active category was "verb" while the most passive was "the adverbs."

To respond to the third research question: Do students' perspectives of learning vocabulary change as a result of the innovation? Frequency comparison of the pre and post-survey regarding vocabulary is reported in table 3. In the pre-survey, $65.4 \%$ of the learners thought learning vocabulary was complex. On the contrary, the post-survey informed that $69.2 \%$ of the students changed their perspective after having applied the innovation.

\begin{tabular}{clllll}
\hline \multirow{3}{*}{ Scales } & \multicolumn{3}{l}{$\begin{array}{l}\text { Vocabulary Complexity } \\
\text { Pre survey }\end{array}$} & $\begin{array}{l}\text { Vocabulary Complexity } \\
\text { Post Survey }\end{array}$ \\
\cline { 3 - 6 } & & Frequency & $\begin{array}{l}\text { Valid } \\
\text { Percent }\end{array}$ & Frequency & $\begin{array}{l}\text { Valid } \\
\text { Percent }\end{array}$ \\
\hline \multirow{3}{*}{ Valid } & Complex & 17 & 65.4 & - & - \\
\cline { 2 - 6 } & Neutral & 3 & 11.5 & 8 & 30.8 \\
\cline { 2 - 6 } & Not complex & 6 & 23.1 & 18 & 69.2 \\
\cline { 2 - 6 } & Total & 26 & 100.0 & 26 & 100.0 \\
\hline
\end{tabular}

Table 3. Comparison of the pre and post survey regarding vocabulary

\section{DISCUSSION}

The results of this study indicate that there is an incidence in students' knowledge of vocabulary directly connected to their reading comprehension. Recent research has suggested that the more significant the vocabulary size is, the better the reading comprehension skills are (Binder et al., 2016; Ibrahim et al., 2016; Skehan, as cited in Ellis, 2005). Catts and Kamhi (2017) sustained that readers bring their previous knowledge to facilitate reading comprehension. One of that previous knowledge can be the meaning and function of the words in context. Lastly, Poulsen and Gravgaard (2016) remarked that syntax aids at making connections to make sense of texts. The difference in means in the reading comprehension of the pre-test and post-test attests these authors' assumptions.

Other studies demonstrated that being aware of the form and meaning of the words facilitated to know how to use specific grammatical components to get a better comprehension (Ellis, 2005; Poulsen and Gravgaard, 2016; Proctor et al., 2012). The findings of the present study are similar to the studies above since it is confirmed that learning vocabulary concerning its form raised students' awareness, and as a consequence facilitated the identification and the correct classification of parts of speech. It was noticeable in this study that learners had a weak knowledge of the function of the words. Raising awareness of the function of words in context through different activities proved to improve their vocabulary size and depth. This improvement can also be related to the connection of how native speakers use vocabulary in the language, in this case in readings, as Lin (2014) pointed out.

As a final point, similarly to what happened in a study conducted in Taiwan, the learners' perspective changed positively after having applied the innovation (Chou, 2018). Table 3 proved that participants went from considering vocabulary difficult to learn to the opposite. This perception may be due to the inclusion of technology in collaborative activities during this process. Students had to record new words in a shared sheet. 
They worked individually and in collaboration within a group. Sadik (2016) found that when students find a friendly application, their perceptions tend to be positive. This study shares the same recommendations for using Google sheets to promote learning in collaborative settings.

\section{CONCLUSIONS}

The present study focused on finding out if classifying words in different parts of speech through the use of Google Sheets had an impact on the reading comprehension skill improvement and facilitated the identification and right classification of new vocabulary in different parts of speech. Furthermore, the study proved that students' perspective changed after having applied the classification of words.

According to the results, it is confirmed that the classification of different parts of speech has potential as a way to improve reading comprehension. Moreover, learning vocabulary form certainly provoked an improvement in reading comprehension. It has been revealed that being aware of the functions of the words helped learners to render the text more comprehensible. It demonstrated that vocabulary depth and reading comprehension are directly related. Incidental vocabulary learning through constant exposure to new words in contexts enhanced the development of students' reading comprehension skills.

Moreover, it has been proven that vocabulary size is not enough to understand texts but also vocabulary depth since it contributed to the correct classification of words. It is worth saying that it was proved that among the four basic parts of speech, adverbs were the most challenging to recognize for learners. For that reason, it is recommended that future studies should emphasize more the use of the adverb.

Bearing in mind that there is a problem in reading in L1, which makes it challenging to learn reading in a new language; and, that Ecuadorian students are not reaching a standard level of English, the implementation of this study showed a contribution. It offered a double benefit. Learners acquired new vocabulary and also enhanced reading comprehension. Moreover, even though the limited education of the participants since most of them had a low-income, it was shown a Cohen's $d=0.81$. According to Bialo and Sivin-Kachala (1996), with just a small effect size, it demonstrates a benefit in the field of study.

Not less importantly, although literature directly related to parts of speech was very little, some studies have proved that grammar is essential to learn vocabulary form and improve in reading comprehension. Hence, they support the aim of the study. The research contribution is in offering a new way to learn vocabulary as a way to improve reading comprehension. Consequently, this study offers researchers a new tool to help learners to learn vocabulary and improve reading comprehension.

Furthermore, the study provides evidence that students' perspective changed positively after having applied the classification of words in Google sheets. Participants' attitudes toward learning vocabulary changed positively. Hence, these positive changes created a better learning environment (Bialo \& Sivin-Kachala, 1996).

\section{Limitations}

The present study was limited to little literature about the effect of the classification of parts of speech in reading comprehension. However, the vast amount of peer-reviewed literature about grammar to learn vocabulary, and consequently to improve reading comprehension was remarkable to support the research.

Second, the number of laboratory hours programmed per week was four initially, but there was a limitation on getting permission to use the laboratory. Due to the fact the language center does not have a laboratory, it was necessary to ask for one that belonged to another faculty. Therefore, blended classes were considered in the process in which three hours were in the laboratory and one in the classroom.

\section{Recommendations}

As it was mentioned before, there is not enough literature about parts of speech influencing the reading comprehension. Therefore, it is recommended to promote future research to improve reading comprehension by teaching parts of speech, as well as research about teaching vocabulary to improve reading comprehension. In this way, the literary enrichment of this field of study is contributed. Additionally, another consideration is to use a control group to reconfirm the real effect of the innovation in the research study.

Moreover, the components of the pre-post survey of vocabulary for reading may be subject to changes depending on the student's level. Since the participants were beginners, the present survey just considered the four basic parts of speech. Therefore, it is recommended to add the other parts of speech in it. 


\section{REFERENCES}

Abdullah, F. (2014). The effect of using padlet on enhancing efl writing performance [Master's thesis]. $A l$ Imam Muhammad Ibn Saud Islamic University. Retrieved from http://www.awej.org/images/Theseanddissertation/ FarahNasserAlgraini/farahalgrainifullthesis.pdf

Bialo, E., \& Sivin-Kachala, J. (1996). The effectiveness of technology in schools: A summary report. SLMQ, 25(1), 1-14. Retrieved from http://www.ala.org/aasl/sites/ala.org.aasl/files/ content/aaslpubsandjournals/slr/edchoice/SLMQ EffectivenessofTechnologyinSchools_InfoPower.pdf

Binder, K. S., Cote, N. G., Lee, C., Bessette, E., \& Vu, H. (2016). Beyond breadth: The contributions of vocabulary depth to reading comprehension among skilled readers. Journal of research in reading, 40(3), 333-343. doi: 10.1111/1467-9817.12069

Cabrera, P., Castillo, L., González, P., Quiñónez, A., \& Ochoa, C. (2018). The impact of using pixton for teaching grammar and vocabulary in the efl ecuadorian context. Teaching English with Technology, 18(1), 53-76. Retrieved from Retrievedfromhttps://files.eric.ed.gov/fulltext/ EJ1170640.pdf

Çakir, A., Ünaldi, I., Arslan, F. Y., \& Kiliç, M. (2016). Effects of reading strategies and depth of vocabulary knowledge on turkish efl learners' text inferencing skills. English Language Teaching, 9(8), 11-20. doi: 10.5539/elt.v9n8p11

Catts, H. W., \& Kamhi, A. G. (2017). Prologue: Reading comprehension is not a single ability. Language, Speech, and Hearing Services in Schools, 48(2), 73. doi: 10.1044/2017 lshss-16-0033

Celce-Murcia, M., Brinton, D., \& Snow, M. (2014). Teaching english as a second or foreign language. Boston: National Geographic Learning/Heinle Cengage Learning.

Chiner, E., \& Garcia-Vera, V. E. (2017). Student computer attitudes, experience and perceptions about the use of two software applications in building engineering. European Journal of Engineering Education, 42(6), 1455-1466. doi: 10.1080/03043797.2017.1306025

Choi, S. P., Lam, S. S., Li, K. C., \& Wong, B. T. (2018). Learning analytics at low cost: At-risk student prediction with clicker data and systematic proactive interventions. Journal of Educational Technology \&5 Society, 21(2), 273290. Retrieved from https://www.j-ets.net/ETS/journals/ $21 \_2 / 23 . p d f$

Chou, I.-C. (2018). Exploring taiwanese students' perceptions of active explicit vocabulary instruction: A case study in an english medium course. International Journal of Education and Literacy Studies, 6(1), 17-26. Retrieved from https://files.eric.ed.gov/fulltext/EJ1172336.pdf

Edwards-Groves, C., \& Kemmis, S. (2016). Pedagogy, education and praxis: understanding new forms of intersubjectivity through action research and practice theory. Educational action research, 24(1), 77-96. doi: 10.1080/09650792.2015.1076730

Ellis, R. (2005). Principles of instructed language learning. System, 33(2), 209-224. doi: 10.1016/j.system.2004.12.006

Flotts, M. P., Manzi, J., Jiménez, D., Abarzúa, A., Cayuman, C., \& García, M. J. (2016). Informe de resultados terce: logros de aprendizaje. [Third Regional Comparative and Explanatory Study TERCE: Learning achievements.]. Retrieved from http://unesdoc.unesco.org/images/

\section{4/002435/243532S.pdf}

Grammarbank. (n.d.). Beginners reading comprehension 4. Retrieved from https://www.grammarbank.com/beginners -reading-comprehension-4.html

Hatami, S. (2017). The differential impact of reading and listening on 12 incidental acquisition of different dimensions of word knowledge. Reading in a Foreign Language, 29(1), 61-85. Retrieved from https://files.eric.ed.gov/ fulltext/EJ1137894.pdf

Hazaea, A. N., \& Alzubi, A. A. (2016). The effectiveness of using mobile on efl learners' reading practices in najran university. English language teaching, 9(5), 8-21. Retrieved from https://files.eric.ed.gov/fulltext/EJ1097574.pdf

Hubbard, P. (2009). Computer assisted language learning: Critical language learning. London: LDN: Routledge.

Ibrahim, E. H. E., Sarudin, I., \& Muhamad, A. J. (2016). The relationship between vocabulary size and reading comprehension of esl learners. English Language Teaching, 9(2), 116-123. Retrieved from https://files.eric.ed.gov/fulltext/ EJ1095578.pdf

Instituto Nacional de Estadísticas y Censos. (2012). Hábitos de lectura en ecuador. [Reading Habits in Ecuador]. Retrieved from http://www.celibro.org.ec/web/img/cms/ ESTUDIO\%20HABITOS\%20DE\%20LECTURA\%20INEC .pdf

Jarvis, H., \& Krashen, S. (2013). Is call obsolete? language acquisition and language learning revisited in a digital age. The Electronic Journal for English as a Second Language, 17(4), 1-6. Retrieved from https://eric.ed.gov/ ?id=EJ1024104

Kartushina, N., Frauenfelder, U. H., \& Golestani, N. (2016). How and when does the second language influence the production of native speech sounds: A literature review. Language Learning, 66 (2), 155-186. doi: 10.1111/lang.12187

Kelley, K., \& Preacher, K. J. (2012). On effect size. Psychological methods, 17(2), 137-152. doi: 10.1037/a0028086

Lin, Y. (2014). Using key part-of-speech analysis to examine spoken discourse by taiwanese efl learners. ReCALL: the Journal of EUROCALL, 27(3), 304-320. doi: $10.1017 / \mathrm{s} 0958344014000408$

Lynn, S. (2015). Q skills for success: Reading and writing. New York, NY: Oxford University Press.

Manowong, S. (2017). Incorporating online tools to promote english reading for efl learners: an action research study. Pasaa Paritat Journal, 32, 98-124. Retrieved from http://www.culi.chula.ac.th/publicationsonline/files/ article2/Uz8VwjDfrZMon32902.pdf

Melinger, A., \& Koenig, J. (2007). Part-of-speech persistence: The influence of part-of-speech information on lexical processes. Journal of Memory and Language, 56(4), 472-489. doi: 10.1016/j.jml.2006.12.001

MM placement test. (n.d.). Mm publications $m m$ online placement test. Retrieved from http://services.overcart.com/ mm_publications_mm_online_placement_test.pdf

Nation, I. (2001). Learning vocabulary in another language. Cambridge: Cambridge University Press. doi: 10.1017/CBO9781139524759

Nunan, D. (1991). Language teaching methodology. New York: Prentice hall.

Oh, E. (2015). Comparative studies on the roles of linguistic knowledge and sentence processing speed in 
12 listening and reading comprehension in an efl tertiary setting. Reading Psychology, 37(2), 257-285. doi: 10.1080/02702711.2015.1049389

Pearson, P. D., Valencia, S. W., \& Wixson, K. (2014). Complicating the world of reading assessment: Toward better assessments for better teaching. Theory into practice, 53(3), 236-246. doi: 10.1080/00405841.2014.916958

Poulsen, M., \& Gravgaard, A. K. D. (2016). Who did what to whom? the relationship between syntactic aspects of sentence comprehension and text comprehension. Scientific Studies of Reading, 20(4), 325-338. doi: 10.1080/10888438.2016.1180695

Proctor, C. P., Silverman, R. D., Harring, J. R., \& Montecillo, C. (2012). The role of vocabulary depth in predicting reading comprehension among english monolingual and spanish-english bilingual children in elementary school. Reading and Writing, 24, 1635-1664. doi: 10.1007/s11145011-9351-6

Purgina, M., Mozgovoy, M., \& Ward, M. (2017). Mall with wordbricks-building correct sentences brick by brick. CALL in a climate of change: adapting to turbulent global conditions-short papers from EUROCALL, 254-259. Retrieved from https://files.eric.ed.gov/fulltext/ED578298 .pdf

Richards, J. C., \& Schmidt, R. W. (2002). Longman dictionary of language teaching and applied linguistics (3rd ed.). London, UK: Longman.

Sadik, A. (2016). Students' acceptance of file sharing systems as a tool for sharing course materials: The case of google drive. Education and Information Technologies, 22(5), 2455-2470. doi: 10.1007/s10639-016-9556-Z

Schachter, P., \& Shopen, T. (2010). Parts of speech systems. Language typology and syntactic description, 1. Retrieved from http://content.schweitzer -online.de/static/catalog_manager/live/media_files/ representation/zd_std_orig__zd_schw_orig/002/215/ 633/9780521581561_content_pdf_-1.pdf

Schmitt, N., \& Meara, P. (1997). Researching vocabulary through a word knowledge framework: Word associations and verbal suffixes. Studies in second language acquisition, 19(1), 17-36. doi: 10.1017/s0272263197001022

Scott, C. (2015). The futures of learning 2: What kind of learning for the 21st century? UNESCO Digital Library. Retrieved from http://unesdoc.unesco.org/images/ 0024/002429/242996e.pdf

Sevilla-Pavón, A. (2016). Affordances of telecollaboration tools for english for specific purposes online learning. World Journal on Educational Technology: Current Issues, 8(3), 218-223. Retrieved from https://files.eric.ed.gov/fulltext/ EJ1142231.pdf

Slabakova, R. (2018). L2 semantics from a formal linguistic perspective. Language Teaching, 51(2), 187-209. doi: $10.1017 / \mathrm{s} 0261444818000071$

Solano, L., Cabrera, P., Ulehlova, E., \& Espinoza, V. (2017). Exploring the use of educational technology in efl teaching: A case study of primary education in the south region of ecuador. Teaching English with technology, 17(2), 77-86. Retrieved from https://files.eric.ed.gov/fulltext/EJ1140683 .pdf

UNESCO. (2014). Enseñanza y aprendizaje para lograr la calidad educativa. [Teaching and Learning: Reaching quality for everyone.] Paris. Retrieved from https://unesdoc.unesco .org/ark:/48223/pf0000226159
Yurtbasi, M. (2015). Building english vocabulary through roots, prefixes and suffixes. Global Journal of Foreign Language Teaching, 5(1), 44-51. doi: 10.18844/gjflt.v5i0.39
How to cite this article (APA):

Granda, G. K. A. \& Ramirez-Avila, M. R. (2020). AtoZ: novas práticas em informação e conhecimento, 9(2), $24-31$. Retrieved from: http://dx.doi.org/ 10.5380 /atoz.v9i2.73526 